\title{
SDH Complex Mutation Analysis
}

National Cancer Institute

\section{Source}

National Cancer Institute. SDH Complex Mutation Analysis. NCI Thesaurus. Code

C158955.

A procedure used to detect and identify mutations in any gene that encodes one of the proteins in the succinate dehydrogenase (SDH) complex. 